\title{
Potent but precarious: When, how, and why national identities have strong impact on attitude formation in response to events
}

Yuval Feinstein, Harvard University and University of Haifa

Over the last few decades, the research pendulum in the field of nationalism studies has swung from the post-war interest in the eruptive, emotional, and sometimes 'dark' side of nationalism that exposes itself most clearly in wartime, in the activity of national liberation movements, and in the actions of the ultranationalist far-right in established nation-states, to a more recent interest in a widely diffused national sentiment (Billig 1995) and the transient (mostly benign) modes of national identification that emerge in various social contexts (Brubaker 2006). While the growing interest in 'everyday' nationalism has de-trivialized the endurance of diffused national identities, the other side of nationalism's Janus face - that is, the capacity of national identities to cause irregular attitudinal and behavioural reactions to changing circumstances - is now often taken-for-granted and thus remains undertheorized.

This article aims to fill this gap in the literature via the development of a theoretical framework, which draws from humanistic philosophy, the sociology of nationalism, political psychology, and the sociology of emotions. The proposed framework highlights and explains the role of emotions, which the sociology of nationalism tends to ignore (Bonikowski 2016) despite the 
fact that national identification is emotionally laden (Berezin 1997). In settled times, the emotional dispositions attached to national identities may remain obscure-'like a soldier's courage in the absence of war' (Bourdieu 2000:149) ${ }^{1}$ — but occasionally (following what I call major 'nation-disrupting events'), national identification evokes intense emotionality (Collins 2004; Rahn, Kroeger, and Kite 1996) that can last for an extended period (Collins $2012)^{2}$

To lay the foundation for the current theory, the next section explores the roots of the profound emotional commitment that most people have to their nations, which is revealed in special circumstances that prompt a transition from 'banal' nationalism (Billig 1995) to 'hot' nationalism. By applying both a cutting-edge conceptualization of nation as a site of symbolic struggles over collective identity (Bonikowski 2016) and core principles of sociological theories of emotions, subsequent sections explain when (that is, in response to which events and processes) nationalism turns from banal to hot, how national identities affect individual-level affective reactions to events, and how these reactions influence the formation of political attitudes. The conclusion presents several hypotheses that derive from the proposed theoretical framework and discusses its limitations and potential extensions.

\section{The nation as an object of identification: potent but precarious}

In the theoretical framework that this article outlines, emotions function as the mechanism that drives attitudinal and behavioural shifts in response to unusual 
events. This section explores the sources of the emotional energy that national subjects experience in response to certain events (in particular to what the subsequent section defines as 'nation-disrupting events'). I show that this emotionality is rooted in a combination of two seemingly contradictory aspects of the way nations are constructed as objects of identification: potency and precariousness.

\section{Potency}

In the introduction to Imagined Communities, Benedict Anderson (1991[1983]) concluded that nationalism gained potency in eighteenth century Western Europe, when it replaced religion as the ideology that transforms 'fatality into continuity, contingency into meaning' (11). Membership in an imagined national community helps individuals overcome their most fundamental anxieties, because nations 'always loom out of an immemorial past, and, still more important, glide into a limitless future' (11-12). Other prominent students of nationalism have also maintained that nationalism functions as a secular replacement for religion in modernity (Greenfeld 1992; Hayes 1926; Hutchinson 2017:9,51; A. D. Smith 2003) and is remarkably successful in winning the hearts and minds of large populations because it provides meaning, continuity, and order to otherwise meaningless, short, and arbitrary lives in increasingly secular societies.

Although nationalism certainly provides answers to existential questions, calling it a 'surrogate religion' (Hutchinson 2017:9; see also A. D. Smith 1986:176) is too simplistic, most obviously because nationalism and 
religion are co-present in most societies and in many cases actually reinforce each other (Brubaker 2012), but primarily because it downplays the degree to which the potency of nationalism stems from the modern conditions of life (rather than the supposed absence or declining importance of religion).

Scholars in the Frankfurt school have been the most forceful advocates of the idea that the conditions of life in modern societies are responsible for the popularity and power of nationalism (Finlayson 1998). In Escape from Freedom, Erich Fromm (1994[1941]) argued that by breaking communal bonds, modernization provided people with more freedoms, but at the same time increased the threat of becoming isolated and powerless (Burston 1991:chap.4; for a review, see McLaughlin 1996). In turn, in Dialectic of Enlightenment, Horkheimer and Adorno (1972[1944]) stressed that the enlightenment, rather than extending individuals' freedom, increased domination and repression, in particular due to a capitalist social organization and industrial mode of production. ${ }^{3}$

Nationalism provides a powerful remedy for the troubles brought about by modernization. According to Fromm (1994[1941]), to cope with the existential state of anxiety that has emerged in modernity, individuals find comfort in large communities organized around authority centres, such as nations and religious groups, because these communities satisfy the need for integration and make their members feel empowered. Finlayson (1998:152-3) concluded that membership in a nation empowers individuals for two complementary reasons. First, national identification brings meaning and 
purpose. In Finlayson's words, 'Nationalism fulfils a utopian function both retroactively in terms of a past golden age, and for the future that awaits the people who seize their 'natural' inheritance and bring their own heaven to this earth'. Second, nationalism is empowering because it makes 'selfdetermination co-terminous with subordination to the collective' and thus, 'through identification with the image of the nation the modern subject can find a self-aggrandizing sense of closure and stability' (152). ${ }^{4}$

\section{Precariousness}

As explained above, having an emotional commitment to a nation proves to be a worthwhile investment because the imagined association with co-nationals creates a 'protective cocoon' (a term I borrow from Giddens [1991]) for individuals that shields them against the ever-lurking existential threats of isolation and meaninglessness in modern life. However, while the nation as an object of identification is potent, it is also precarious. Benedict Anderson's notion of 'imagined community' (Anderson 1991[1983]) hints at the reasons for this precariousness. Anderson uses the term 'imagined' to reflect the fact that 'members of even the smallest nation will never know most of their fellow-members, meet them, or even hear them, yet in the minds of each lives the image of their communion' (6). A fundamental characteristic of nations, therefore, is that they do not exist ontologically. Rather, their 'existence' depends on individuals who do not know each other embracing the belief that they are part of one nation (Gellner 1983; Seton-Watson 1977). 
While the 'existence' of the nation depends on the imagination work of its members (and outsiders), the development of national subjectivity in individuals depends on a pre-existing ideal of a nation. The relationship between the subject and the idealized nation is reciprocal. The nation, which is represented by institutions, beliefs, and ideas, is simultaneously constitutive of the individual self (for most people, their personal narratives and sense of place in the world are closely tied to their belief in national narratives and culture, see Glover 1997:18; Papadakis 1998:160; Tamir 1997:232) and constituted by (or within) individuals' sense of self via their identification (Finlayson 1998:158). The first part of this claim is clear: The development of national identities in individuals depends on the pre-existence of national narratives and culture. The second part of the claim, however, raises two important questions: To what extent does the existence of the nation depend on the beliefs of individuals? How exactly do individuals' imaginations produce the nation?

Seton-Watson's (1977:5) claim that 'a nation exists when a significant number of people in a community consider themselves to form a nation, or behave as if they formed one' (a description Anderson echoes in 'imagined communities') implies that the consideration of actual, specific individual subjectivities may become redundant, because the nation is conceptualized as some sort of collective artefact that does not depend on the cognition of any particular individual. How then can scholars conceptualize the 'nation' as simultaneously an 'external' object of identification and the outcome of 
subjective imagination? What is the bond between subjects that makes them a 'nation' but is nonetheless a fruit of their imagination? The answer, following Slavoj Zizek (1993:201), is a shared fantasy about the existence of the nation that is not reducible to the nation's symbolic representations. In Zizek's words,

The bond linking together [a community's] members always implies a shared relationship toward a Thing...This relationship toward the Thing, structured by means of fantasies, is what is at stake when we speak of the menace to our 'way of life' presented by the Other: it is what is threatened when, for example, a white Englishman is panicked because of the growing presence of 'aliens'. What he wants to defend is not reducible to the socalled set of values that offer support to national identity. National identification is by definition sustained by a relationship toward the Nation qua Thing.

The 'Thing"' that Zizek points to is, as Finlayson (1998:155) explained, 'a 'fantasy' of consistency and order, a fantasy that behind the numerous rituals and cultural patterns of life there is some structuring agent, in this case the essential nation'.

The nation's precariousness follows from the radical state of the 'nation' as a phantasmal object (see also Beisel 1980), because behind any fantasy is a narrative. As Jaqueline Rose (1996:5) explained, fantasy 'always contains a historical reference in so far as it involves, alongside the attempt to arrest the present, a journey through the past'. As a phantasmal object of 
identification, the nation depends on the reproduction of a mythical narrative about its past, which is constructed by selectively remembering certain events and periods while forgetting others (Renan 1996[1882]), and by reinterpreting the commemorated events in light of current ideological and practical aspirations (Coakley 2004; Zerubavel 1995:chap.1). National narratives are constructed, reproduced, and presented via various types of media and artefacts (Hodgkin and Radstone 2003:11) such as history books, archaeological sites, holiday rituals, memorial sites and ceremonies, statues and paintings in museums and open public spaces, the rhetoric of public figures, novels, and the ritualistic practice of 'traditions' that seem to link the present directly to the past (Hobsbawm 1983). These media jointly generate and reproduce mythical thinking about a nation's origin and its golden age as well as both major triumphs and defeats that serve as lessons for the present (Glover 1997).

Crucially, however, a nation is not a homogenous cultural unit based on a single, unified narrative. In contrast to the previously dominant tradition in nationalism research of focusing on essential elements of each country's national identity (e.g., Kohn 1944; Lipset 1990), scholars now acknowledge that nations are sites of symbolic struggles between competing narratives concerning the nation's meaning (Bonikowski 2016). This contestation highlights questions such as who is a legitimate member of the nation, what are the core values of the nation, and what is the nation's role in the world (Bonikowski 2016). Even more profoundly, nations are sites of struggle 
between competing historical narratives. This type of intra-national contestation is not limited to the question of which events and periods in the history of the nation are important enough to be commemorated, but, crucially, also encompasses the meaning of historical events and periods and their moral implications (for reviews, see Olick and Robbins 1998; Vinitzky-Seroussi 2002).

Borrowing from Ignatieff (1998:56), nationhood 'is not a skin, but a mask, constantly repainted'. Therefore, the fundamental concern of national subjects is that the answer to the question 'Who are we?' (or 'What is profoundly common to us?') might shift, thus causing a loss of the consistency, order, and meaning provided by the mythical and fantasized nation. Such a shift may be brought about by change in the political balance of power between sub-sets of a national community that have competing narratives about the nation or as a consequence of the nation's engagement with significant 'others', either migrant or native ethnic minorities or foreign actors such as the nation's enemies. An anticipatory fear of change can also bring about this type of shift: people may interpret (with the help of opinion leaders) social, political, or economic changes as harbingers of identity changes.

In sum, national identification is a potentially powerful force that motivates individuals to deviate from their normal attitudes and routine behaviour because it embodies two fundamental properties: first, an emotional potency based on its power to shield against the existential threats that have 
strengthened in modernity, and second, the precariousness of the nation as an object of identification whose 'existence' ('as we know it') is hanging by a thin thread of phantasmal belief that is rooted in a contested historical narrative.

The theoretical framework developed in this article for explaining major shifts in public attitudes in response to certain events, emphasizes that different national narratives offer competing answers to a set of core questions-What is the shared legacy of our national past? How does this legacy define the moral core of our nation, our present problems, and our future goals? — that jointly serve as a master framework for individuals' interpretations of certain events. Ultimately, disagreement about the answers to these questions can transform even a confrontation with an external 'them' (for example, the enemy in armed conflicts, immigrants, and non-national ethnic minorities) into a passionate struggle about the meaning of 'us'. I use the label 'nation-disrupting events' to refer to events that become loaded with this kind of meaning. The following section further examines nation-disrupting events and their connection to national narratives.

\section{Nation-disrupting events and the re-appropriation of the past}

In the framework proposed by McDonnell, Bail, and Tavory (2017), people perceive unusual events as 'puzzles' to be solved. As they attempt to solve these puzzles, people consult public discourse about the event. Symbolic politics theory (Sears 1993) predicts that discourse about events will be convincing if it adopts symbols that are cognitively consistent with the long- 
standing predispositions that individuals acquire through socialization, such as party identification, political ideology, and racial prejudice. For this reason, public opinion about policy issues and political figures usually remains stable or changes slowly and thus is quite predictable (Page and Shapiro 1992). Further, in periods of relative stability, political attitudes are clustered in ideological camps (Gries 2014). Occasionally, however, major events produce attitudinal (and sometimes also behavioural) shifts among the public. This occurs most clearly during rally-round-the-flag periods of wars that boost the popularity of the head of the state and public trust in state institutions (Feinstein 2016). However, this is not the only type of event that produces an attitudinal shift, for example, these shifts can occur during campaign periods in national elections, which alter the political interest and engagement of many people who otherwise are not very engaged in politics.

In the terminology proposed here, an event (or a series of events) becomes 'nation-disrupting' when it creates a widespread sense that the collective identity of the nation is at stake. Such an event is perceived as an evaluation of the current state of the nation vis-à-vis its idealized mythical image, and the possibility of identifying a significant gap between the actual and the mythical makes space for modifying the idealized image of the nation. In Bonikowski's (2016:431-2) terms, these events punctuate nationhood-asusual.

Rogers Brubaker has asserted that "what defines us as a nation' at any given moment is no more than a temporary equilibrium in an ongoing 
argument about what defines us as a nation' (Brubaker 2004:123). Nationdisrupting events produce a deep sense of insecurity among the public, because they break or threaten to break that equilibrium: they open the door for a discussion of the nation, which can introduce novel and creative ways of envisioning the nation (see also Sewell 1996:867) or at least alter the relative prevalence of existing visions.

In most cases, however, the sense of insecurity does not stem directly from an event, but rather is produced by the symbolic actions of political leaders who seek to frame the circumstances as pertaining to the 'true' essence or virtue of the nation, which should be celebrated or requires protection (Bonikowski 2016:438). This type of rhetoric draws temporal comparisons (Mummendey, Klink, and Brown 2001; Nigbur and Cinnirella 2007) between the present state of the nation and its actions and either the perceived national past or what the public perceives as the original or ideal moral essence of the nation based on the national mythology. Such discourse often becomes nostalgic, contrasting an inadequate present with an idealized past (Hutcheon and Valdés 2000:21), thus making the mythical memories about what the nation used to be or how it used to behave the 'blueprints for the future' (A. D. Smith 1986:177). This type of 'future-oriented nostalgia' (Cashman 2006:148) is especially recognizable in two types of phenomena: nationalist movements that promote the restoration of the nation to a glorious past of national liberty, self-determination, and a unique way of life (Garvin 1986; Muro 2005) and social and political revolutions that search the collective history for a source 
for inspiration. As Karl Marx (1977[1852]:301) described in The Eighteenth

\section{Brumaire of Louis Bonaparte,}

The awakening of the dead in those revolutions served the purpose of glorifying the new struggles, not of parodying the old; of magnifying the given task in imagination, not of fleeing from its solution in reality; of finding once more the spirit of revolution, not making its ghost walk about again.

In the aftermath of major events, the re-appropriation of the national past (Hutchinson 2017:10) in order to assess the present and set goals for the future may include reviving nostalgic memories of a golden age and great deeds of the nation that should be mimicked, as well as traumatic memories of humiliating defeats that should not be repeated and moral sins that require collective atonement or moral redemption (Hodgkin and Radstone 2003; Vinitzky-Seroussi 2002).

Re-appropriation of the past is especially effective if current events are perceived as similar to historical events, because this 'convert[s] situations to scenarios' (P. Smith 2005:14): The narrative of the nation's history becomes a guide for how to respond to current events. Political leaders often do not wait for the public to spontaneously make such comparisons, but rather publically analogize the present to the past, proposing that the solution to current problems can be found in the lessons that 'we' learned from 'our' past successes and mistakes, and portraying the current situation as an opportunity to restore the nation to a glorious, mythical past. ${ }^{5}$ 
Hitler's rhetoric is a primary example of this strategy: He analogized the Germans under his rule to the Teutonic Knights who were caught in a Crusade-like war against the Jews that would determine who would govern the world for the next thousand years (Blain 1988). Following Germany's defeat in World War II, Hitler himself became a useful analogy for leaders of other countries who sought to mobilize public support for later wars: They described the leaders of opposing nations as a new version of Hitler and compared the current military action to the struggle to defeat Nazi Germany. This analogy was employed by British political leaders during the 1956 Suez Crisis (P. Smith 2005:79) and by U.S. politicians during the 1990-1991 crisis in the Persian Gulf (Kellner 1992) and the 2003 Iraq War .

In some instances, political leaders extend the analogy by implying that current events could potentially lead to a replication of past successes or mistakes. For example, during the Gulf War, political leaders who drew an analogy between Saddam Hussein and Adolph Hitler implied that postponing the intervention would have consequences similar to those resulting from the delay of U.S. intervention in World War II (Winkler 2006:114). In another example, during the Balkan wars in the 1990s, Serbian nationalist propaganda elicited traumatic memories of the massacres against Serbs committed by the Croat Ustaše during World War II and thus provoked Serbs' fear of a reoccurrence of such atrocities (Denich 1994; Oberschall 2000).

While re-appropriation of the past is especially pronounced in struggles against external enemies in wars of liberation and interstate wars, it 
also frequently takes centre-stage in intra-national politics of identity. Internal contention over the meaning of the nation intensifies during national elections, in which candidates sometimes employ a romantic discourse highlighting the nation's cultural traditions and special way of life, which must be protected or restored (Godreau 2002; Polletta and Callahan 2017). National elections are, therefore, often less a debate about policy per se than a competition between different visions of the essence of the nation and its unique way of life and values (Bonikowski, Feinstein and Bock 2019). Consequently, both the euphoria in the winning camp, whose members feel that 'our way' has prevailed, and the depression among those in the losing camp, who fear that the nation's downfall is imminent, are reflections of fantasies about the future that are rooted in mythical beliefs about the national past.

\section{The mechanism driving the relationship between nation-disrupting events and attitudes: the role of emotions}

Previous research has established that people use their affective reactions to events and policies as informational shortcuts for attitude formation (for review, see Clore, Gasper, and Garvin 2000). Therefore, when nationdisrupting events evoke strong affective reactions (because they challenge taken-for-granted beliefs about the home nation), some individuals deviate from their usual range of attitudes and actions (Rahn, Kroeger, and Kite 1996), while others become more entrenched in their attitudes. Crucially, however, whether the initial affective reaction to a nation-disrupting event is negative or 
positive depends on deeply held beliefs about the home nation and allusions to these beliefs that are invoked in public discourse about events.

In order to translate this simple claim into a nuanced theoretical framework that can produce useful working hypotheses, I draw from two complementary sociological theories of emotions: Burke's (1991) identity theory of emotions and Kemper's (2013:chap.13) status-power theory. Both theories address the emotions that individuals experience as members of groups (see also E. R. Smith, Seger, and Mackie 2007), but the two theories differ in their emphases on the specific conditions and mechanisms that generate these emotions.

Burke's identity theory of emotions (Burke 1991; see also Stryker and Burke 2000) suggests that during social interactions, actions that are in line with identity standards (i.e., how individuals believe they should act based on their identity) elicit pride, while actions that are not in line with identity standards elicit shame. The same principle applies to a national subject's reaction to a nation-disrupting event - the emotional reaction is determined by the individual's assessment of whether the nation's actions in the present align with the idealized image of the nation (Rahn, Kroeger, and Kite 1996).

The reaction to the events of the 1962 Cuban Missile Crisis illustrates this process. Opinion leaders and many members of the American public considered Kennedy's tough talk against the Soviet Union and Cuba and his decision to impose a marine blockade on the latter country as being in line with important standards of collective national identity, including (among 
others) following the Monroe Doctrine, being courageous, standing behind core national principles, and not succumbing to the threats of communist enemies (Feinstein 2016). ${ }^{6}$ In the wake of Kennedy's handling of the crisis (and the reinforcement of identity standards), the average level of general happiness increased and Kennedy's job approval rating jumped from 60 to 75 per cent (Feinstein 2016).

Whereas Burke's theory highlights introspection focused on comparing a person or group's actual actions to their idealized course of action, Kemper's (2013:chap.13) status-power theory focuses on the confrontation between a group and an 'other' and the perceived implications of this confrontation for the power and status that the ingroup has vis-à-vis the external other. Specifically, Kemper proposed that situations or actions that lead to a loss of power (or that are perceived as such) elicit fear, and situations that lead to a loss of status (or are perceived as such) elicit anger. For example, in the aftermath of the 9/11 terrorist attacks, some Americans initially reacted with fear due to a perceived loss of power, and later reacted with anger due to a perceived loss of collective status (Kemper 2002). In contrast, a situation or action that is perceived as increasing the power or status of the group produces positive emotions such as pride, hope, and excitement.

Kemper's theory asserts that affective reactions are a fundamental tendency of individuals under perceived threats to the group from another group. However, in line with my overall arguments in this article, I contend that situations of perceived conflict with external actors produce the strongest 
affective reactions when the interpretive framework that people embrace compares the current nation to its idealization. For example, as mentioned earlier, when George H. W. Bush sought to mobilize public support for the Gulf War, he compared the Iraqi invasion of Kuwait to World War II and Saddam Hussein to Adolf Hitler. This example shows that meaning may be assigned to present events by drawing two analogies simultaneously: The nation's current opponent is compared to historical enemies, and the present or expected actions are compared to 'our' reactions to similar circumstances in the past. Seen in this light, Kemper's status-power theory and Burke's identity theory of emotions are two sides of the same coin. Both attribute negative or positive affective reactions to individuals' assessments of whether their nation's value (based on their own valuation, rather than the valuation of external others) has declined (either due to the nation's failed or immoral deeds, thus evoking embarrassment or shame, or due to others' humiliating actions, thus producing anger) or increased (thus producing pride).

The public's assessment of whether the nation gained or lost symbolic value and whether the nation's identity standards were met or violated is not static, but can change as events unfold and individuals reappraise the situation. ${ }^{7}$ For example, immediately after the September 11 attacks, most Americans experienced a negative emotional reaction because they viewed the attacks as an apocalyptic nightmare and a violation of America's status as a powerful and proud nation (Kemper 2002). Later, however, most Americans came to view the situation as an opportunity to display the American spirit, 
epitomized by the actions of the United Flight 93 passengers and the firefighters at Ground Zero. During this period, rituals of solidarity (Collins 2004), embodied in spontaneous and organized memorial services as well as ubiquitous displays of national symbols, became a collective presentation of 'us at our best', a celebration of the nation's ideal self-image. This interpretive shift resulted in a positive emotional reaction — including increased levels of pride, confidence, and hope - and boosted both the popularity of President Bush and trust in national institutions (Feinstein 2020).

Importantly, the transformation of events into nation-disrupting events does not always result in the blurring of intra-national ideological divisions (as occurs in rally-round-the-flag periods, see Feinstein 2016; Feinstein 2018). Indeed, nation-disrupting events sometimes strengthen such divisions - these events produce contrasting reactions if subsets of society assign different meanings to events because they have differing beliefs about the essence of the nation and its history (and thus different levels of receptiveness to the political elite's interpretations of the meaning of events).

A brief review of two specific political developments in the United States illustrates this pattern. During the 1999 NATO intervention in Kosovo, a rally behind military engagement in the Balkans occurred mostly among Democrats, while in 2003 the rally behind the invasion of Iraq occurred primarily among Republicans (Feinstein 2017). While a thorough investigation of the U.S. public reaction to these two military operations is beyond the scope of the current discussion, the principles outlined in this 
section suggest that for Americans on the left side of the political-ideological spectrum, the declared goal of stopping an atrocity in Kosovo produced positive emotions because it resonated with a 'Jeffersonian' creedal nationalism that assigns the United States the task of defending other peoples against authoritarian oppressors. In contrast, the framing of the invasion of Iraq as part of America's war against its terrorist enemies found more resonance (and thus produced positive emotions) among the political right, where a 'Jacksonian' ethnoreligious nationalism that highlights the need to protect the American nation against external and internal enemies and maintain the United States' supreme international power and status is especially prevalent. ${ }^{8}$

\section{Conclusion}

This article introduced a theoretical framework for examining why, when, and how national identities have strong impact on the formation of attitudes in response to major 'national' events. I moved through the process of theorization with the explicit intention of reasserting the intensity (of both the content and the affective bond) that characterizes national identities, which in the past decades has been somewhat overshadowed by the growing interest in banal expressions of nationalism in everyday life. At the same time, I sought to achieve this goal without falling into the trap of applying an essentialist view of national identities (Brubaker 1996; Surak 2012). Instead, throughout 
the article I assumed the complex, contested, and situated character of socially constructed national identities.

In brief, the theoretical framework outlined in this article suggests that the combination of two factors - the emotional commitment of individuals to their nation, which protects them from existential threats, and the precariousness of the nation as a phantasmal belief that depends on the reproduction of contested historical narratives - makes national identification a potentially powerful force that can drive individuals to deviate from their normal political attitudes and routine behaviour, which may be motivated by various factors (e.g., ideological or partisan identity, identification with an ethnic/racial group, personal financial interests, or a general lack of interest in politics), toward attitudes and behaviour that are motivated primarily by a desire to maintain or restore what national subjects believe to be an ideal image of their nation. Nation-disrupting events - events that threaten or promise to alter what individuals believe to be the core elements of their nation — produce high levels of emotionality. The subsequent attitudes that individuals express depend on the character of their affective reaction, which is itself determined by the meaning they assign to events based on both their profound beliefs about the essence of the home nation and their receptiveness to the elite's cues about the meaning of events.

This theoretical framework generates five preliminary hypotheses for future research about public reactions to major 'national' events and policies. First, individuals who perceive an event as testing the nation's true character 
and values (i.e., as a 'nation-disrupting event') should experience the strongest affective reactions. Second, the perception of events as 'nation-disrupting' should be most common among individuals who compare (spontaneously or in response to elite cues) present challenges and reactions of national leaders to meaningful periods in the history of the nation. Third, in the aftermath of a nation-disrupting event, individuals who come to believe that current policy aligns with the perceived idealized image of the nation are likely to experience a positive affective reaction, and thus their attitudes toward both the policy and the leaders who proposed it are likely to be supportive; in contrast, individuals who perceive a contradiction between current policies and the idealized image of the nation are likely to experience a negative affective reaction and have less supportive attitudes toward the policy and leaders. Fourth, the public should be more likely to interpret events as nationdisrupting (leading to widespread affective and attitudinal reactions) when the political elite (and the media) assign this kind of profound meaning to events. Fifth, the public's affective and attitudinal reactions should be polarized if the political elite offers contradictory interpretations of the implications of events and reactions thereto for national identity (e.g., are they in line with or in opposition to core national values), and should be relatively homogeneous if the political elite assign a uniform meaning to nation-disrupting events and reactions.

The theoretical framework developed in this article has two main limitations that should motivate future extensions of the work. Namely, the 
current framework does not consider the tendency of national identities to change over time, nor does it include a systematic examination of the influence of other identities (e.g., those based on ethnicity/race, gender, religion, political party, and ideology).

First, the current framework requires holding national identities constant (so-to-speak); however, it is important to acknowledge that national identities change over time, and more specifically, to consider how identities might change in response to events. Because nation-disrupting events provoke competition between different idealizations of the nation, these events can lead to profound changes in national identities and/or their relative popularity among the public. Further, as part of the public discourse about nationdisrupting events, political leaders may call forth national memories—both nostalgic and traumatic — not only to influence the public's attitudes about current events, but also to take advantage of the moment to mobilize popular support for a grand national agenda (Cashman 2006:153; Hutchinson 2017:17; Özyürek 2006:154). The pursuit of this broader goal transforms the public discourse from a narrowly focused debate on how to interpret and respond to current events to a more profound struggle over the meaning of the nation and the content of national ideologies (Boym 2008:25; Kuzio 2006; Tismaneanu 1998:15; Yu 2009:23-5). Even wars - arguably the most likely of all types of events to produce a 'rally-round-the-flag' effect of closing-ranks behind the national leadership and its policies (Feinstein 2016) — can evoke a confrontation among rival national ideologies (Papadakis 1998). 
When events engender an open battle between different views of the nation, the conflict can have long-term effects on identities and political attitudes. I briefly mention three possible outcomes of these identity struggles. The first possible outcome is identity polarization, which occurred among Greek Cypriots when the 1974 Turkish invasion deepened the cleavage between Hellenic nationalism and pan-Cyprian nationalism (Papadakis 1998). A second possible outcome of nation-disrupting events is a shift in the balance of political power between competing national identities. Such a shift occurred among Jewish Israelis in the aftermath of the al-Aqsa Intifada (2000-2005) and led to the current political dominance of xenophobic and militant ultranationalism (Del Sarto 2017; Feinstein and Ben-Eliezer 2019). A third possible result of nation-disrupting events is the emergence of new national identities and ideologies via either dialectical processes - as happened in postSoviet and Yugoslav countries (Brubaker 1996:20)—or the amalgamation of existing national ideologies. ${ }^{9}$

Because the proposed theoretical framework focuses on the role of national identities, a second limitation of the framework is the lack of systematic consideration of the role of other competing or supplemental identities and systems of beliefs such as ethnicity/race, gender, religion, political party, and ideology. This issue is beyond the scope of the current discussion (but see for example Gilroy 2013; Nagel 1998; Sidanius et al. 1997; Yuval-Davis 1993), but I offer two preliminary hypotheses. First, the likelihood that national identity will influence attitude formation in response to 
events depends on the salience of national identity compared to an individual's other identities, especially partisan and social-ideological identities. ${ }^{10}$ Individuals whose national identity, ideological identity, and partisan identity are all highly salient and closely linked are less likely to experience a shift in political attitudes, because as Martin and Desmond (2010:9) explained, these individuals 'have preorganized the world so as to make effortless and affective associations'. In contrast, individuals who have relatively weak ideological and political identities but a salient national identity are most likely to experience shifts in attitudes.

Second, I hypothesize that subnational groups (e.g., ethnic/racial groups) may respond to an event (or a series of events) with different political attitudes and behaviour because they make different assessments of whether the events damaged or improved the status of their group and its point of view within the nation. Two recent developments in the United States - the rage of middle-class white Americans that led to the growth of the Alt-Right and the election of Donald Trump, and the resentment conveyed by women and ethnic/racial minorities in the mass protests that followed Trump's electionshow how different idealized images of the nation lead to intra-national variation in attitudes and behaviour at moments of hot nationalism during or after major nation-disrupting events. Further, these examples demonstrate the relational nature of the formation of attitudes in the course of an increasingly heated competition between subgroups that hold contrasting idealized images of the nation. 
I am cautiously optimistic that the principles that guided the theorybuilding in this article will also be useful for the development of theoretical frameworks for analysing how other types of identity (e.g., religious, gender, or even professional) influence attitudes and behaviour. This type of theoretical work requires overcoming the ambiguity of the term 'identity', which can have either a weak or strong meaning and can assume either fluidity or stability (Brubaker and Cooper 2000). The discussion in this article suggests that future theoretical frameworks should (a) examine intra-group variation and struggles over the meaning of 'collective' identities; (b) pay attention to the situated nature of identities (i.e., ask what activates an identity and through which mechanisms the identity influences attitudes and behaviour); and (c) be aware that 'collective' identities have a dual naturealthough they are socially constructed and thus dynamic and fluid, these identities may remain quite stable and salient for extended periods in the lives of individuals. Applying these principles will improve the concept of identity by restoring its clarity and analytical usefulness, and thus will facilitate further theory-building.

\footnotetext{
${ }^{1}$ I thank Zeynep Ozgen for calling my attention to Bourdieu's 'soldier' metaphor.

${ }^{2}$ A shift from 'cold cognition' to 'hot cognition' (see Cerulo 2010 for a review).
} 
${ }^{3}$ This claim echoes similar concerns about shifts in modernity voiced by some of the founding fathers of sociology: Ferdinand Tönnies's described a transition from community (Gemeinschapft), in which individuals are bounded to their family in 'weal and woe', to society (Gessellschaft), to which one goes 'as one goes into a strange country' (Tönnies 1955[1887]:38). Emil Durkheim argued that anomie permeates modern societies because the organic division of labour is not matched by a moral framework for regulating social life (Durkheim 1985[1893]:46). George Simmel described modern life as 'overburdened with objective content and material demands' (Simmel and Hughes 1949:257). Max Weber claimed that in modernity, individuals are alienated and disenchanted because magic and mystique have been replaced by science and reason (Weber 1946[1917]:155).

${ }^{4}$ This tendency toward self-aggrandizing identification with the nation (see alsp Greenfeld 2006; Lebow 2008) can generate (and indeed has generated) two destructive outcomes. Under certain conditions, national identification may drive individuals to embrace fascist ideologies, as forcefully argued by the Frankfurt school scholars. In addition, a belief in the uniqueness of the nation often transforms into a belief in its superiority to other nations and even a sense of 'mission' in the world (for examples of such transformations in the aftermath of World War I and during World War II, see Hayes [1926] and Kohn [1944], respectively). Further, the 'chauvinist mythmaking' of nationalist agents (Van Evera 1994:27), including certain schools and journalists, and some members of the political elite, seeks to establish precisely this link 
between national identification and chauvinism. Once individuals begin to believe in national superiority, this belief becomes emotionally loaded because it satisfies (as Fromm argued, see McLaughlin 1996:256) a fundamental human need for recognition and respect from others, and thus, as Norbert Elias stressed (1998[1956]:89), produces immense narcissistic gratification.

${ }^{5}$ Historical and sociological-historical studies provide ample evidence that economic or political uncertainty makes people highly susceptible to being moved by nationalist rhetoric and thus feeling that the essence of the nation might be at risk . Therefore, the likelihood that events will produce individuallevel shifts in political attitudes via national identification may also depend on individuals' assignment to social categories such as class and cohort that differ in their levels of exposure to uncertainty (Bonikowski 2016:433-4;

Bonikowski 2017; Boym 2008; Ignatieff 1998; Kuzio 2006; McLaughlin 1996; Pešić 1993; Tismaneanu 1998).

${ }^{6}$ This reinforcement of national identity standards was especially important in the wake of the humiliating failure of the U.S.-sponsored coup in Cuba during the Bay of Pigs invasion — when the United States let others do its dirty work and thus did not act in a way that reflected identity standards (Feinstein 2016). ${ }^{7}$ For discussion of reprisal as a mechanism of emotions, see Ellsworth and Scherer (2003) and Lazarus (2001).

${ }^{8}$ For a discussion of this division within American nationalism, see Lieven (2004). 
${ }^{9}$ An example of the latter type of transformation is Charles de Gaulle's ideology as a president: In response to the difficult experiences in World War II and the subsequent futile combat against the insurgencies in Indochina and Algeria, de Gaulle integrated principles from the Republican and Bonapartist traditions in a new national ideology that sought to use French's presidential democracy to restore France's great power and status in Europe (Hutchinson 2017:46).

${ }^{10}$ By salience, I mean the likelihood of evoking a particular identity in different situations (Stryker and Serpe 1982:206).

\section{References}

Anderson, B. R. 1991[1983]. Imagined Communities: Reflections on the Origin and Spread of Nationalism. London; New York: Verso.

Beisel, D. R. 1980. 'The Group-Fantasy of Early German Nationalism, 18001815'. The Journal of Psychohistory 8:1.

Berezin, M. 1997. Making the Fascist Self: The Political Culture of Interwar Italy. Cornell University Press.

Billig, M. 1995. Banal Nationalism. London; Thousand Oaks, Calif.: Sage. Blain, M. 1988. 'Fighting Words: What we can Learn from Hitler's Hyperbole'. Symbolic Interaction 11:257-76.

Bonikowski, B. 2016. 'Nationalism in Settled Times'. Annual Review of Sociology 42:427-49. 
Bonikowski, B.2017. 'Ethno-nationalist Populism and the Mobilization of Collective Resentment'. The British Journal of Sociology 68:181-213.

Bonikowski, Bart, Yuval Feinstein and Sean Bock. 2019. "The Polarization of Nationalist Cleavages and the 2016 U.S. Presidential Election." Paper presented at the annual meeting of the American Sociological Association.

Bourdieu, P. 2000. Pascalian Meditations. Stanford, Calif.: Stanford University Press.

Boym, S. 2008. The Future of Nostalgia. Basic Books.

Brubaker, R. 2012. 'Religion and Nationalism: Four Approaches'. Nations \& Nationalism 18:2-20.

Brubaker, R. 2004. 'In the Name of the Nation: Reflections on Nationalism and Patriotism'. Citizenship Studies 8:115-27.

Brubaker, R. 1996. Nationalism Reframed: Nationhood and the National Question in the New Europe. Cambridge [England]; New York: Cambridge University Press.

Brubaker, R. 2006. Nationalist Politics and Everyday Ethnicity in a Transylvanian Town. Princeton: Princeton University Press.

Brubaker, R. and Cooper F. 2000. 'Beyond 'Identity". Theory and Society 29:147.

Burke, P. J. 1991. 'Identity Processes and Social Stress'. American Sociological Review 56:836-49.

Burston, D. 1991. The Legacy of Erich Fromm. Harvard University Press. 
Cashman, R. 2006. 'Critical Nostalgia and Material Culture in Northern Ireland'. Journal of American Folklore 119:137-60.

Cerulo, K. A. 2010. 'Mining the Intersections of Cognitive Sociology and Neuroscience'. Poetics 38:115-32.

Clore, G. L., Gasper K. and Garvin E. 2000. 'Affect as Information'. Pp. 12145 in Handbook of Affect and Social Cognition, edited by J. P. Ford. Mahwah, NJ: Lawrence Erlbaum Associates.

Coakley, J. 2004. 'Mobilizing the Past: Nationalist Images of History'. Nationalism and Ethnic Politics 10:531-60.

Collins, R. 2004. 'Rituals of Solidarity and Security in the Wake of Terrorist Attack'. Sociological Theory 22:53-87.

Collins, R. 2012. 'Time-Bubbles of Nationalism: Dynamics of Solidarity Ritual in Lived Time'. Nations and Nationalism 18:383-97.

Del Sarto, R. A. 2017. Israel Under Siege: The Politics of Insecurity and the Rise of the Israeli Neo-Revisionist Right. Washington, DC: Georgetown University Press.

Denich, B. 1994. 'Dismembering Yugoslavia: Nationalist Ideologies and the Symbolic Revival of Genocide'. American Ethnologist 21:367-90.

Durkheim, E. 1985[1893]. 'The Division of Labour in Society'. Pp. 23-47 in Readings from Emile Durkheim, edited by Kenneth Thompson. London and New York: Routledge. 
Elias, N. 1998[1956]. 'Involvement and Detachment'. Pp. 84-91 in The Norbert Elias Reader a Biographical Selection, edited by J. Goudsblom and S. Mennell. Oxford UK and Malden MA: Blackwell Publishers.

Ellsworth, P. C. and Scherer, K. R. 2003. 'Apprisal Processes in Emotions'. Pp. 572-95 in Handbook of Affective Sciences, edited by R. J. Davidson, K. R. Scherer. and H. H. Goldsmith. New York: Oxford University Press. Feinstein, Yuval. 2016. "Rallying around the President: When and Why Do Americans Close Ranks Behind Their Presidents During International Crisis and War?". Social science history 40(2):305-38.

Feinstein, Yuval. 2017. "The Rise and Decline of "Gender Gaps" in Support for Military Action: United States, 1986-2011." Politics \& Gender 13(4):618-55.

Feinstein, Yuval. 2018. "One Flag, Two Rallies: Mechanisms of Public Opinion in Israel During the 2014 Gaza War." Social science research 69:65-82.

Feinstein, Yuval and Uri Ben-Eliezer. 2019. "Failed Peace and the Decline in Liberalism in Israel: A Spiral Model." Mediterranean Politics 24(5):568-91.

Feinstein, Yuval. 2020. "Applying Sociological Theories of Emotions to the Study of Mass Politics: The Rally-Round-the-Flag Phenomenon in the United States as a Test Case." The Sociological Quarterly:1-26. 
Finlayson, A. 1998. 'Psychology, Psychoanalysis and Theories of Nationalism'. Nations and Nationalism 4:145-62.

Fromm, E. 1994[1941]. Escape from Freedom. Macmillan.

Garvin, T. 1986. 'The Anatomy of a Nationalist Revolution: Ireland, 18581928'. Comparative Studies in Society and History 28:468-501.

Gellner, E. 1983. Nations and Nationalism. Ithaca, NY: Cornell University Press.

Giddens, A. 1991. Modernity and Self-Identity: Self and Society in the Late Modern Age. Stanford university press.

Gilroy, P. 2013. There Ain'T no Black in the Union Jack. Routledge.

Glover, J. 1997. 'Nations, Identity, and Conflict'. The Morality of Nationalism:18.

Godreau, I. 2002. 'Changing Space, Making Race: Distance, Nostalgia, and the Folklorization of Blackness in Puerto Rico'. Identities: Global Studies in Culture and Power 9:281-304.

Greenfeld, L. 1992. Nationalism: Five Roads to Modernity. Cambridge, Mass.: Harvard University Press.

Greenfeld, L. 2006. Nationalism and the Mind: Essays on Modern Culture. Oxford: Oneworld.

Gries, P. 2014. The Politics of American Foreign Policy: How Ideology Divides Liberals and Conservatives Over Foreign Affairs. Stanford University Press. 
Hayes, C. J. H. 1926. Essays on Nationalism. New York: The Macmillan Company.

Hobsbawm, E. J. 1983. 'Introduction: Inventing Traditions'. Pp. 1-14 in The Invention of Tradition, edited by E. J. Hobsbawm and T. O. Ranger. Cambridge, UK \& New York: Cambridge University Press.

Hodgkin, K. and Radstone, S. 2003. Contested Pasts: The Politics of Memory. Routledge.

Horkheimer, M. and Adorno, T. W. 1972[1944]. Dialectic of Enlightenment. New York: Continuum Pub. Co.

Hutcheon, L. and Valdés, M. J. 2000. 'Irony, Nostalgia, and the Postmodern: A Dialogue'. Poligrafías 3:1998-2000.

Hutchinson, J. 2017. Nationalism and War. Oxford University Press.

Ignatieff, M. 1998. The Warrior's Honor: Ethnic War and the Modern Conscience. Macmillan.

Kellner, D. 1992. The Persian Gulf TV War. Boulder: Westview Press.

Kemper, T. D. 2013. Status, Power and Ritual Interaction: A Relational Reading of Durkheim, Goffman and Collins. Ashgate Publishing, Ltd.

Kemper, T. D. 2002. 'Predicting Emotions in Groups: Some Lessons from September 11'. Pp. 53-68 in Emotions and Sociology, edited by J. Barbalet. Oxford: Blackwell Publishing.

Kohn, H. 1944. The Idea of Nationalism: A Study in its Origins and Background. New York: Macmillan Company. 
Kuzio, T. 2006. 'Ukraine is Not Russia: Comparing Youth Political Activism'. SAIS Review of International Affairs 26:67-83.

Lazarus, R. S. 2001. 'Relational Meaning and Discrete Emotions'. Pp. 37-67 in Appraisal Processes in Emotions: Theory, Methods, Research, edited by K. R. Scherer, A. Schorr and T. Johnstone. Oxford: Oxford University Press.

Lebow, R. N. 2008. A Cultural Theory of International Relations. Cambridge, UK ; New York: Cambridge University Press.

Lieven, A. 2004. America Right Or Wrong: An Anatomy of American Nationalism. New York: Oxford University Press.

Lipset, S. M. 1990. Continental Divide: The Values and Institutions of the United States and Canada. Psychology Press.

Martin, J. L. and Matthew Desmond. 2010. 'Political Position and Social Knowledge'. Sociological Forum 25:1-26.

Marx, K. 1977[1852]. 'The Eighteenth Brumaire of Louis Bonaparte'. Pp. 300325 in Karl Marx: Selected Writings, edited by David McLellan. Oxford University Press, USA.

McDonnell, T. E., Christopher A. Bail and Iddo Tavory. 2017. 'A Theory of Resonance'. Sociological Theory 35:1-14.

McLaughlin, N. 1996. 'Nazism, Nationalism, and the Sociology of Emotions: Escape from Freedom Revisited'. Sociological Theory:241-61. 
Mummendey, A., Klink, A. and Brown, R. 2001. 'Nationalism and Patriotism: National Identification and Out-group Rejection'. British Journal of Social Psychology 40:159-72.

Muro, D. 2005. 'Nationalism and Nostalgia: The Case of Radical Basque Nationalism'. Nations and Nationalism 11:571-89.

Nagel, J. 1998. 'Masculinity and Nationalism: Gender and Sexuality in the Making of Nations'. Ethnic and Racial Studies 21:242-69.

Nigbur, D. and Cinnirella, M. 2007. 'National Identification, Type and Specificity of Comparison and their Effects on Descriptions of National Character'. European Journal of Social Psychology 37:672-91.

Oberschall, A. 2000. 'The Manipulation of Ethnicity: From Ethnic Cooperation to Violence and War in Yugoslavia'. Ethnic and Racial Studies 23:982-1001.

Olick, J. K. and Robbins, J. 1998. 'Social Memory Studies: From 'collective Memory' to the Historical Sociology of Mnemonic Practices'. Annual Review of Sociology 24:105-40.

Özyürek, E. 2006. Nostalgia for the Modern: State Secularism and Everyday Politics in Turkey. Duke University Press.

Page, B. I. and Shapiro, R. Y. 1992. The Rational Public: Fifty Years of Trends in Americans' Policy Preferences. Chicago: University of Chicago Press. 
Papadakis, Y. 1998. 'Greek Cypriot Narratives of History and Collective Identity: Nationalism as a Contested Process'. American Ethnologist 25:149-65.

Pešić, V. 1993. 'The Cruel Face of Nationalism'. Journal of Democracy 4:1003.

Polletta, F. and Callahan, J. 2017. 'Deep Stories, Nostalgia Narratives, and Fake News: Storytelling in the Trump Era'. American Journal of Cultural Sociology 5:392-408.

Rahn, W. M., Kroeger, B. and Kite, C. M. 1996. 'A Framework for the Study of Public Mood'. Political Psychology:29-58.

Renan, E. 1996[1882]. 'What is a Nation?' Pp. 42-55 in Becoming National: A Reader, edited by Geoff Eley and Ronald G. Suny. New York: Oxford University Press.

Rose, J. 1996. States of Fantasy. Oxford University Press.

Sears, D. O. 1993. 'Symbolic Politics: A Socio-Psychological Theory'. Pp. 113,113-149 in Explorations in Political Psychology, edited by S. Iyengar and W. McGuire. Durham, NC: Duke University Press.

Seton-Watson, H. 1977. Nations and States: An Inquiry to the Origins of Nations and the Politics of Nationalism. London: Methun.

Sewell, W. H. 1996. 'Historical Events as Transformations of Structures: Inventing Revolution at the Bastille'. Theory and Society 25:841-81. 
Sidanius, J., Feshbach, S., Levin, S., and Pratto, F. 1997. 'The Interface between Ethnic and National Attachment: Ethnic Pluralism Or Ethnic Dominance?' The Public Opinion Quarterly 61:102-33.

Simmel, G. and Hughes, E. C. 1949. 'The Sociology of Sociability'. American Journal of Sociology 55:254-61.

Smith, A. D. 1986. The Ethnic Origins of Nations. Oxford, UK New York, NY, USA: B. Blackwell.

Smith, A. D. 2003. Chosen Peoples. Wiley Online Library.

Smith, E. R., Charles R. Seger and Diane M. Mackie. 2007. 'Can Emotions be Truly Group Level? Evidence regarding Four Conceptual Criteria'. Journal of Personality and Social Psychology 93:431.

Smith, P. 2005. Why War?: The Cultural Logic of Iraq, the Gulf War, and Suez. Chicago: University of Chicago Press.

Stryker, S. and Serpe, R. T. 1982. 'Commitment, Identity Salience, and Role Behavior: Theory and Research Example'. Personality, Roles, and Social Behavior 119:218.

Stryker, S. and Burke, P. J. 2000. 'The Past, Present, and Future of an Identity Theory'. Social Psychology Quarterly 63:284-97.

Surak, K. 2012. 'Nation-Work: A Praxeology of Making and Maintaining Nations'. European Journal of Sociology/Archives Européennes De Sociologie 53:171-204. 
Tamir, Y. 1997. 'Pro Patria Mori! Death and the State'. Pp. 227-41 in The Morality of Nationalism, edited by Robert McKin and Jeff McMahan. New York: Oxford University Press.

Tismaneanu, V. 1998. 'Fantasies of Salvation: Democracy'. Nationalism and Myth in Post-Communist Europe Princeton University Press, Princeton.

Tönnies, F. 1955[1887]. Community and Association:(Gemeinschaft Und Gesellschaft). Routledge \& Paul.

Van Evera, S. 1994. 'Hypotheses on Nationalism and War'. International Security 18:5-39.

Vinitzky-Seroussi, V. 2002. 'Commemorating a Difficult Past: Yitzhak Rabin's Memorials'. American Sociological Review:30-51.

Weber, M. 1946[1917]. 'Science as Vocation'. Pp. 129-79 in From Max Weber: Essays in Sociology, edited by Charles W. Mills and Hans H. Gerth. New York: Oxford University Press.

Winkler, C. 2006. In the Name of Terrorism: Presidents on Political Violence in the Post-World War II Era. Albany: State University of New York Press.

Yu, H. 2009. Media and Cultural Transformation in China. Routledge.

Yuval-Davis, N. 1993. 'Gender and Nation'. Ethnic and Racial Studies 16:62132.

Zerubavel, Y. 1995. Recovered Roots: Collective Memory and the Making of Israeli National Tradition. University of Chicago Press.

Žižek, S. 1993. Tarrying with the Negative: Kant, Hegel, and the Critique of 
Ideology. Duke University Press. 